\title{
FURTHER EVIDENCE FOR SYNERGISM BETWEEN LH AND FSH IN THE INDUCTION OF OVULATION IN RATS; LACK OF EFFECTS OF PROLACTIN
}

\author{
A. P. LABHSETWAR* \\ Pharmaceuticals Division, ICI Ltd, Alderley Park, Macclesfield, Cheshire
}

(Received 13th December 1971, accepted 13th Fanuary 1972)

\begin{abstract}
Summary. Attempts were made to induce premature ovulation on the day of pro-oestrus in the 4-day cyclic rat by LH, FSH and/or prolactin administered a day earlier. Doses of $5 \mu \mathrm{g} \mathrm{LH}$ and $15 \mu \mathrm{g} \mathrm{FSH}$, when given alone, induced partial ovulation in a few animals but the combination induced normal ovulation in $93 \%$ of the rats. Ovine prolactin given alone failed to induce ovulation and, when given in combination with LH, FSH or both, did not exert synergistic effects on ovulation. These data provide additional evidence that $\mathrm{LH}$ and FSH interact to induce ovulation in the normal oestrous cycle and that the ovulating hormone is composed of at least LH and FSH.
\end{abstract}

Ovulation occurs between 01.00 and 02.00 hours on the day of oestrus in the 4-day cyclic rat (Everett, 1961). Administration of LH on the day before prooestrus, i.e. dioestrus, provokes ovulation on the following day, i.e. a full $24 \mathrm{hr}$ before the expected time, in a proportion of rats. Both the incidence and rate of ovulation, however, are lower than in rats blocked with antioestrogen or barbiturates and given the same dose of LH at pro-oestrus (Brown-Grant, 1967; Labhsetwar, 1971). This could result from the refractory state of the ovaries but the mating stimulus on the night of dioestrus in rats primed with oestrogen provokes normal ovulation $24 \mathrm{hr}$ earlier on the day of pro-oestrus (Aron, Asch \& Roos, 1966; Labhsetwar, unpublished observations). It is obvious that exogenous LH is not a substitute for the ovulating hormone released from the pituitary gland in response to the mating stimulus. If this is the case, then a combination of LH, FSH and/or prolactin might induce ovulation on this day similar to that provoked by the stimulus provided by mating. The possible rôle of prolactin in ovulation needs to be considered in view of a sharp rise in prolactin secretion observed on the afternoon of pro-oestrus (Kwa \& Verhofstad, 1967; Amenomori, Chen \& Meites, 1970). These considerations prompted us to examine the synergism between LH, FSH and/or prolactin in inducing premature ovulation in the oestrous cycle. The synergism between LH and FSH has been demonstrated earlier in 4-day cyclic rats blocked with either an antioestrogen (Labhsetwar, 1970a) or chlorpromazine (Harrington \& Bex, 1970).

* Present address: The Worcester Foundation for Experimental Biology, Shrewsbury, Mass. 01545, U.S.A. 
The Wistar-derived rats of the Alderley Park strain I were maintained on a $14 \mathrm{hr}$ light/10 hr dark ratio and provided free access to food and tap water. Vaginal smears were taken daily and only those rats which had at least one (and frequently more) 4-day oestrous cycles were used in the experiments. Luteinizing hormone (NIH-LH-S-14), FSH (NIH-FSH-S-6) and prolactin (luteotrophic hormones from sheep pituitary, Sigma Co., London, with a potency of 20 to 50 i.u. $/ \mathrm{mg}$ ) were made up in physiological saline and injected intravenously $(0.5 \mathrm{ml}$ injection) through a tail vein in conscious animals to eliminate

TABLE 1

INDUGTION OF PREMATURE OVULATION ON THE DAY OF PRO-OESTRUS BY LH, FSH AND/OR PROLACTIN GIVEN TO 4-DAY CYCLIC RATS

\begin{tabular}{|c|c|c|c|c|c|}
\hline Group & Gonadotrophin & $\begin{array}{c}\text { Dosel } \\
\text { rat }\end{array}$ & $\begin{array}{l}\text { No. of rats ovulating/ } \\
\text { no. of rats in group }\end{array}$ & $\begin{array}{c}\text { No. of oval } \\
\text { rat ovulating } \\
\text { (Mean } \pm \text { S.E. })\end{array}$ & $\begin{array}{c}\text { Rats with pro-oestrus } \\
\text { smears / } \\
\text { no. of rats in group }\end{array}$ \\
\hline $\begin{array}{l}\text { A } \\
\text { B } \\
\text { C } \\
\text { D }\end{array}$ & $\begin{array}{l}\text { Control-oestrus } \\
\text { Control-pro-oestrus } \\
\text { LH }\end{array}$ & $\begin{array}{c}0.5 \mathrm{ml} \\
-- \\
5 \mu \mathrm{g} \\
2 \mu \mathrm{g}\end{array}$ & $\begin{array}{l}20 / 20 \\
0 / 5 \\
6 / 15 \\
2 / 5\end{array}$ & $\begin{array}{l}11 \cdot 2 \pm 0 \cdot 5 \\
0 \\
5 \cdot 3 \pm 1 \cdot 3^{*} \\
3 \cdot 5 \pm 0 \cdot 5^{*}\end{array}$ & $\begin{array}{l}0 / 20 \ddagger \\
5 / 5 \\
12 / 15 \\
4 / 5\end{array}$ \\
\hline $\begin{array}{l}\mathbf{E} \\
F\end{array}$ & FSH & $\begin{array}{r}15 \mu \mathrm{g} \\
5 \mu \mathrm{g}\end{array}$ & $\begin{array}{l}1 / 5 \\
0 / 5\end{array}$ & $\begin{array}{l}4 \cdot 0 \\
0\end{array}$ & $\begin{array}{l}5 / 5 \\
5 / 5\end{array}$ \\
\hline $\begin{array}{l}\mathrm{G} \\
\mathrm{H} \\
\mathrm{I}\end{array}$ & $\mathbf{L} \cdot \mathbf{H}+\mathrm{FSH}$ & $\begin{array}{r}5 \mu \mathrm{g} \\
15 \mu \mathrm{g} \\
5 \mu \mathrm{g} \\
15 \mu \mathrm{g} \\
2 \mu \mathrm{g} \\
5 \mu \mathrm{g}\end{array}$ & $\begin{array}{c}4 / 5 \\
10 / 10 \\
3 / 5\end{array}$ & $\begin{array}{l}9.0 \pm 2.5 \dagger \\
8 \cdot 1 \pm 0.7 \dagger \\
3.7 \pm 0.7^{*}\end{array}$ & $\begin{array}{c}4 / 5 \\
10 / 10 \\
5 / 5\end{array}$ \\
\hline $\begin{array}{l}\mathrm{J} \\
\mathrm{K} \\
\mathrm{L}\end{array}$ & $\begin{array}{l}\text { Prolactin } \\
\text { Prolactin } \\
+\mathrm{LH}\end{array}$ & $\begin{array}{c}15 \text { i.u. } \\
15 \text { i.u. } \\
5 \mu \mathrm{g} \\
15 \text { i.u. } \\
5 \mu \mathrm{g}\end{array}$ & $\begin{array}{l}0 / 5 \\
5 / 5 \\
4 / 5\end{array}$ & $\begin{array}{l}0 \\
4 \cdot 6 \pm 1 \cdot 5^{*} \\
5 \cdot 5 \pm 1 \cdot 04^{*}\end{array}$ & $\begin{array}{l}5 / 5 \\
5 / 5 \\
5 / 5\end{array}$ \\
\hline M & $\begin{array}{l}\text { Prolactin } \\
+ \text { FSH }\end{array}$ & $\begin{array}{l}15 \text { i.u. } \\
15 \mu \mathrm{g}\end{array}$ & $1 / 5$ & 5 & $5 / 5$ \\
\hline $\mathrm{N}$ & $\begin{array}{l}\mathrm{LH} \\
+ \text { FSH } \\
+ \text { Prolactin }\end{array}$ & $\begin{array}{l}5 \mu \mathrm{g} \\
15 \mu \mathrm{g} \\
15 \text { i.u. }\end{array}$ & $4 / 5$ & $5 \cdot 7 \pm 1 \cdot 9 *$ & $4 / 5$ \\
\hline
\end{tabular}

* $P<0.05$ when compared with Group A.

$\dagger$ Not significantly different from Group A $(P>0.05)$.

$\$$ All rats had cornified smears.

possible effects of anaesthesia. All injections were given at 14.00 hours on the day before pro-oestrus, i.e. the day of dioestrus, and the animals were killed on the following morning, i.e. the expected day of pro-oestrus. Both Fallopian tubes were removed and searched for tubal ova as described earlier (Labhsetwar 1970b).

Control animals killed on the morning of oestrus had a normal complement of 
ova (Group A, Table 1) but no tubal ova could be found in rats killed on the morning of pro-oestrus (Group B). Administration of 2 and $5 \mu \mathrm{g} \mathrm{LH}$ (Groups $\mathrm{C}$ and $\mathrm{D}$ ) or 5 and $15 \mu \mathrm{g}$ FsH (Groups $\mathrm{E}$ and $\mathrm{F}$ ) induced ovulation but both the incidence and the ovulation rate were lower than in Group A $(P<0.05)$. However, when $5 \mu \mathrm{g} \mathrm{LH}$ and $15 \mu \mathrm{g}$ FSH were combined, fourteen out of fifteen animals showed tubal ova in numbers not significantly different from the normal complement in Group A $(P>0.05)$ in two different experiments (Groups $\mathrm{G}$ and $\mathrm{H})$. A combination of $2 \mu \mathrm{g} \mathrm{LH}$ and $5 \mu \mathrm{g}$ FsH did not improve the yield beyond that in Group D receiving $2 \mu \mathrm{g}$ LH alone. Administration of 15 i.u. prolactin failed to induce ovulation in any of the five animals (Group J) but the same dose in combination with $5 \mu \mathrm{g}$ LH caused ovulation in nine out of ten rats (Groups $\mathrm{K}$ and L) but the ovulation rate was still below normal $(P<0.05)$. Prolactin also proved ineffective in inducing ovulation when given with FSH (Group M) but when given in combination with $5 \mu \mathrm{g}$ LH and $15 \mu \mathrm{g}$ of FSH, which together induced full ovulation (Groups $\mathrm{G}$ and $\mathrm{H}$ ), the prolactin reduced the yield of ova significantly in one experiment (Group $\mathrm{N}, P<0.05$ when compared with Group A).

With the exception of Group A, which showed cornified smears, all other groups showed pro-oestrous type smears, i.e. predominantly containing nucleated epithelial cells as found in Group B. Thus, induction of premature ovulation was not associated with any detectable changes in the normal progression of the vaginal cycle.

The results in Groups $\mathrm{G}$ and $\mathrm{H}$ support the view that LH and FSH synergize to induce ovulation in rats, confirming earlier reports (Labhsetwar, 1970a; Harrington \& Bex, 1970). These results cannot be attributed to contamination of the FSH preparation with LH since, according to the supplier, such a contamination is less than $0.06 \mu \mathrm{g}$ in a dose of $15 \mu \mathrm{g}$ FsH. The data should not be interpreted to mean that the rat pituitary produces equivalents of $5 \mu \mathrm{g} \mathrm{LH}$ and $15 \mu \mathrm{g}$ FSH for ovulation since different combinations of gonadotrophins may produce similar results. It appears that ovine prolactin cannot be substituted for FSH to obtain synergism with LH and the results emphasize the specificity of FSH in synergism with $\mathbf{L H}$ for the induction of ovulation. It is doubtful if the prolactin surge on the afternoon of pro-oestrus (Kwa \& Verhofstad, 1967; Amenomori et al., 1970) plays a significant rôle in ovulation since ovine prolactin either alone or in combination with LH and/Or FSH did not induce normal ovulation. If anything, it reduced the response (ovulation rate) to LH and FSH (Group $\mathrm{N}$ versus Groups $\mathrm{G}$ and $\mathrm{H}$ ) in one experiment but this needs to be confirmed in further studies. However, before a definite rôle for prolactin in ovulation can be excluded, experiments need to be done with rat prolactin which may yield different results in rats from those observed here with ovine prolactin. This could also be true of rat LH and FSH but species specificity for these gonadotrophins has not been demonstrated.

I thank Miss G. Mitchell for providing technical assistance and the Endocrine Study Section, NIH, for the gift of gonadotrophins. 


\section{REFERENCES}

Amenomori, Y., Chen, C. \& Meites, J. (1970) Serum prolactin levels in rats during different reproductive states. Endocrinology, 86, 506.

Aron, C., Asch, G. \& Roos, J. (1966) Triggering of ovulation by coitus in the rat. Int. Rev. Cytol. 20, 139.

Brown-Grant, K. (1967) The effects of a single injection of progesterone on the oestrus cycle, thyroid gland activity and uterine-plasma concentration ratio for radio-iodide in the rat. $\mathcal{F}$. Physiol., Lond. 190, 101.

EVERETT, J. W. (1961) The mammalian reproductive cycle and its controlling mechanism. In: Sex and Internal Secretions, 3rd edn, Vol. 1, p. 497, Ed. W. C. Young. Williams \& Wilkins, Baltimore.

HARRINGTON, E. \& BEx, R. (1970) Ovulation in the rat as a result of synergism between follicle stimulating hormone and luteinizing hormone. Endocr. jap. 17, 387.

Kwa, H. G. \& Verhorstad, F. (1967) Prolactin levels in the plasma of female rats. F. Endocr. 39, 455.

LabHSETwar, A. P. (1970a) Synergism between LH and FSH in the induction of ovulation. F. Reprod. Fert. 23, 517.

LABHSETWAR, A. P. (1970b) The role of oestrogens in spontaneous ovulation: evidence for positive oestrogen feedback in the 4-day oestrous cycle. F. Endocr. 47, 481.

LABHSETWAR, A. P. (1971) Exploration of site(s) of action of progesterone in inhibiting ovulation in rats. Biol. Reprod. 5, 115 . 